Article

\title{
On Long-Term Stability of Metallic Glasses
}

\author{
Dmitri V. Louzguine-Luzgin ${ }^{1,2, *}$ and Jing Jiang ${ }^{3}$ \\ 1 WPI Advanced Institute for Materials Research, Tohoku University, Sendai 980-8577, Japan \\ 2 MathAM-OIL, National Institute of Advanced Industrial Science and Technology (AIST), \\ Sendai 980-8577, Japan \\ 3 Institute for Materials Research, Tohoku University, Sendai 980-8577, Japan; j.jiang.imr@gmail.com \\ * Correspondence: dml@wpi-aimr.tohoku.ac.jp; Tel./Fax: +81-22-217-5957
}

Received: 4 September 2019; Accepted: 2 October 2019; Published: 4 October 2019

check for updates

\begin{abstract}
Thermal stability of different types of metallic glasses and partially crystalline alloys stored for at least 15 years at ambient conditions was tested in the present work by differential scanning calorimetry in comparison with that of the original alloys tested in the as-cast state in the earlier works. The structure of the naturally aged alloys was also studied by X-ray diffractometry. The structure of a couple of selected alloys was also tested by transmission electron microscopy. Most of the alloys retained their initial structure and showed only a moderate decrease in the crystallization temperature. Only those alloys which showed visible surface oxidation (Cu-Zr-system based) were partly transformed into a crystalline state forming micron-scale $\mathrm{Cu}$ particles in air at ambient conditions.
\end{abstract}

Keywords: metallic glass; thermal stability; structure; crystallization

\section{Introduction}

Glassy alloys/metallic glasses [1] as well as bulk (volumetric) metallic glasses (BMGs) [2,3] are metastable at room temperature and crystallize on heating above the temperature $\left(T_{x}\right)$ which, as well as the glass-transition temperature $\left(T_{g}\right)$ (measured as an inverse glass-transition from a glassy state to a supercooled liquid one on heating) depends on the heating rate used $[4,5]$. Some of glassy alloys (usually called amorphous alloys) crystallize directly on heating [6] while others upon fast enough heating initially transform to a supercooled liquid which crystallizes at a higher temperature. In some alloys such a transition drastically affects the crystallization reaction which changes from an eutectic one below $T_{g}$ to a primary one above it [7]. The glassy alloys with a low $T_{x}$ crystallize even at room temperature $[8,9]$ but for the majority of glassy alloys the process is very slow $[10,11]$.

The time-temperature-transformation (TTT) diagrams created in the isothermal mode (or under continuous heating) are useful for comparison of the thermal stabilities of different glasses against devitrification and for selection of the heat treatment regimes. Such diagrams have been created for various metallic glasses, for example, $\mathrm{Zr}-[12], \mathrm{Au}-$ [13] and Pd-based [14,15]. Comparison of the long-term thermal stabilities of different metallic glasses was also performed using continuous heating transformation (CHT) diagrams [16]. Early transition metals: Ti-, Zr- and Hf-based metallic glasses were found to have a similar time-temperature gradient of the curves related to the beginning of crystallization independently from those initial devitrification products (crystal or quasicrystal) and transformation mechanism. Metalloid-rich Si- and Ge-based glasses exhibited quite high long-term thermal stability. Late transition metals: $\mathrm{Cu}$ - and Ni-based metallic glasses showed high thermal stability at a short time scale. CHT diagrams were also recalculated from the isothermal TTT ones [17] using a method similar to that used in Reference [18]. These calculations predict lifetime temporal stability of metallic glasses at room temperature if those $T_{x}$ values are at least $\sim 200 \mathrm{~K}$ above that [19] and no other factors except for temperature are taken into account. In the past thermal stability of 
metallic glasses was usually tested on heating. In the present work we test long-term thermal, and partly chemical stability, of different metallic glasses at ambient conditions.

\section{Experimental Procedure}

Ingots of the studied alloys were prepared by arc-melting the mixtures of pure elements $>99.9$ mass\% purity in an argon atmosphere (99.9995\%) while the ingots of Mg-based alloys were produced by induction melting. From these alloys, ribbon samples of about $0.02 \mathrm{~mm}$ in thickness and $1.0 \mathrm{~mm}$ in width were prepared by rapid solidification of the melt on a single copper roller at the wheel surface velocity of $42 \mathrm{~m} / \mathrm{s}$. All samples were stored in air placed in a zipped plastic box to avoid drastic contamination with organic dust for at least 16 years at ambient conditions.

The phase composition of the glassy ribbon samples was studied by conventional X-ray diffractometry (XRD) using D8 Advance Diffractometer (Bruker Co., Karlsruhe, Germany) with a monochromatic $\mathrm{CuK}_{\alpha}$ radiation. The thermal stability was tested by differential scanning calorimetry (DSC) using Seiko Exstar SII 6300 calorimeter (Seiko Instruments \& Electronics Ltd., Tokyo, Japan) heat-flux type machines at a heating rate of $0.67 \mathrm{~K} / \mathrm{s}$ in a high-purity Ar atmosphere containing more than $99.9995 \%$ of Ar. The calorimeter was calibrated using pure $\mathrm{Sn}$ in the low temperature range and using $\mathrm{Al}$ in the high temperature one. Each sample was measured twice up to complete crystallization. The data of the second run were used as a baseline for each measurement.

Transmission electron microscopy (TEM) investigations of two selected samples were carried out using a JEM 2010F microscope (JEOL Co. Ltd., Tokyo, Japan) operating at $200 \mathrm{kV}$. Bright-field, dark-field, and high-resolution TEM (HRTEM) images, as well as selected area electron (SAED) and nanobeam diffraction (NBD) patterns were obtained. The microstructure of the naturally oxidized samples was examined by a HITACHI S-4800 scanning electron microscope (SEM) (Hitachi Co. Ltd., Tokyo, Japan) carried out at $15 \mathrm{kV}$ equipped with an energy dispersive X-ray (EDX) spectrometer.

\section{Results}

Table 1 shows chemical compositions of the studied alloys, the literature reference number, the number of years passed after preparation, the temperatures obtained by DSC, and the calculated temperature differences such as $\Delta T_{g}=T_{g}{ }^{i}-T_{g}{ }^{a}, \Delta T_{x}=T_{x}{ }^{i}-T_{x}{ }^{a}$ and $\Delta T_{r}{ }^{x}=\Delta T_{x} / T_{x}{ }^{i}$ as indicated in the table. The original (initial) DSC traces were obtained earlier [20-29]. A few selected DSC traces (both of initial and aged samples) are shown in Figure 1a. As one can see, although the crystallization temperature $\left(T_{x}\right)$ is slightly reduced after more than 15 years of aging the reduction is only a few Kelvin even for the alloys with rather low $T_{x}$. It is in line with high room temperature thermal stability of metallic glasses predicted by the extrapolation of the high-temperature part of CHT and TTT diagrams [16,19].

The glass-transition temperature $\left(T_{g}\right)$ as a result of room-temperature aging is either decreased or increased even in the case of similar alloys. For example, see the $\Delta T_{g}$ values for the $\mathrm{Cu}_{55} \mathrm{Zr}_{30} \mathrm{Ti}_{10} \mathrm{Au}_{5}$ and $\mathrm{Cu}_{55} \mathrm{Zr}_{30} \mathrm{Ti}_{10} \mathrm{Pd}_{5}$, as well as $\mathrm{Ni}_{55} \mathrm{Zr}_{30} \mathrm{Ti}_{10} \mathrm{Pd}_{5}$ and $\mathrm{Ni}_{55} \mathrm{Zr}_{30} \mathrm{Ti}_{10} \mathrm{Pt}_{5}$ alloys, respectively, (Table 1 ) which exhibited the opposite changes in $T_{g}$. It is likely connected with the baseline instability close to $T_{g}$ owing to heat release during structural relaxation.

Three independent measurements were performed for the naturally aged $\mathrm{Ti}_{50} \mathrm{Ni}_{22} \mathrm{Cu}_{25} \mathrm{Sn}_{3}$ alloy and the resulted DSC curves are shown in Figure $2 b . T_{x}$ defined by the intersection of two tangents to the curve before and after the inflection point for each measurement is $754 \mathrm{~K}$ which leads to the standard error value below $1 \mathrm{~K} . T_{g}$ values of 695,697 , and $700 \mathrm{~K}$ lead to the average value of $697 \mathrm{~K}$ with much larger uncertainty compared to $T_{x}$. The standard error is $\pm 1.5 \mathrm{~K}$ while if the Student's criterion is taken into account owing to small number of measurements (low degree of freedom) then the confidence interval (C.I.) is $\pm 3.4 \mathrm{~K}$. Thus, the heat release during structural relaxation shields glass transition, which makes measurement of $T_{g}$ much less accurate.

The $\mathrm{Al}_{85} \mathrm{Ni}_{5} \mathrm{Co}_{2} \mathrm{Y}_{6} \mathrm{Pd}_{2}$ alloy having amorphous + nanoscale $\mathrm{Al}$ structure is also quite stable against the room-temperature aging (even though Al-based glass-forming liquids are very fragile [30]) as well 
as the $\mathrm{Si}_{45} \mathrm{Al}_{20} \mathrm{Fe}_{10} \mathrm{Ge}_{10} \mathrm{Ni}_{5} \mathrm{Gr}_{5} \mathrm{Zr}_{5}$ one containing nanoscale precipitates of a solid solution of $\mathrm{Si}$ in cF8 Ge. The nanoparticles also exhibit high stability at room temperature. $\Delta T_{r}{ }^{x}$ for all alloys studied, except for those affected by corrosion (see the notes below Table 1), is less than $1 \%$.

The X-ray diffraction patterns of typical alloys are shown in Figure 2. Most of the studied alloys retained those initial glassy (Figure 2a) or partly crystalline (Figure 2b) structure as well as the original silver metallic color. The diffraction patterns of partially crystalline samples also correspond to those of the as-cast samples studied earlier. No visible changes in the $X$-ray diffraction patterns are found. Transmission electron microscopy observation also confirmed preservation of the glassy structure even in an alloy with rather low crystallization temperature (Figure 3a) and in a partly crystalline one (Figure 3b). No traces of crystallinity are seen within the glassy area even when studied using nanobeam diffraction with the probe size of $1 \mathrm{~nm}$.

Table 1. Chemical compositions of the studied alloys in the as-prepared state (marked as initial) and after room-temperature aging for some time (marked as aged), the reference number (Ref), the number of years passed after preparation $(\mathrm{NY})$ and the related temperatures as well as temperature differences absolute $\left(\Delta T_{g}\right.$ and $\left.\Delta T_{x}\right)$, and relative $\left(\Delta T_{r}^{x}\right)$.

\begin{tabular}{|c|c|c|c|c|c|c|c|c|c|}
\hline \multirow[b]{2}{*}{ Alloy } & \multirow[b]{2}{*}{ Ref } & \multirow[b]{2}{*}{ NY } & \multirow[b]{2}{*}{$\Delta T_{g}$} & \multirow[b]{2}{*}{$\Delta T_{x}$} & \multirow{2}{*}{$\begin{array}{l}\Delta T_{r}^{x} \\
\times 100\end{array}$} & \multicolumn{2}{|c|}{ Initial } & \multicolumn{2}{|c|}{ Aged } \\
\hline & & & & & & $T_{g}^{i}(\mathrm{~K})$ & $T_{x}{ }^{i}(\mathrm{~K})$ & $T_{g}^{a}(\mathrm{~K})$ & $T_{x}^{a}(\mathrm{~K})$ \\
\hline $\mathrm{Al}_{85} \mathrm{Gd}_{8} \mathrm{Ni}_{5} \mathrm{Co}_{2}$ & 20 & 19 & 4 & 3 & 0.52 & 554 & 575 & 550 & 572 \\
\hline $\mathrm{Al}_{85} \mathrm{Sm}_{8} \mathrm{Ni}_{5} \mathrm{Co}_{2}$ & 21 & 18 & 1 & 2 & 0.35 & 557 & 575 & 556 & 573 \\
\hline $\mathrm{Mg}_{86} \mathrm{Mm}_{4} \mathrm{Ni}_{10}$ & 22 & 17 & - & 3 & 0.66 & - & 456 & - & 453 \\
\hline $\mathrm{Mg}_{86} \mathrm{Y}_{2} \mathrm{Mm}_{2} \mathrm{Ni}_{10}$ & 22 & 17 & - & 1 & 0.22 & - & 451 & - & 450 \\
\hline $\mathrm{Cu}_{55} \mathrm{Zr}_{30} \mathrm{Ti}_{10} \mathrm{Au}_{5}$ & 23 & 17 & 3 & 3 & 0.38 & 744 & 787 & 741 & 784 \\
\hline $\mathrm{Cu}_{55} \mathrm{Zr}_{30} \mathrm{Ti}_{10} \mathrm{Pd}_{5}$ & 24 & 17 & -6 & 2 & 0.26 & 735 & 784 & 741 & 782 \\
\hline $\mathrm{Cu}_{57.5} \mathrm{Ni}_{2.5} \mathrm{Zr}_{30} \mathrm{Ti}_{10}$ & 25 & 18 & 3 & 1 & 0.13 & 705 & 749 & 702 & 748 \\
\hline $\mathrm{Ni}_{55} \mathrm{Zr}_{30} \mathrm{Ti}_{10} \mathrm{Pd}_{5}$ & 26 & 16 & -4 & 0 & 0.00 & 787 & 811 & 791 & 811 \\
\hline $\mathrm{Ni}_{55} \mathrm{Zr}_{30} \mathrm{Ti}_{10} \mathrm{Pt}_{5}$ & 26 & 16 & 5 & 3 & 0.36 & 816 & 845 & 811 & 842 \\
\hline $\mathrm{Ni}_{60} \mathrm{Zr}_{30} \mathrm{~V}_{10} *$ & - & 18 & -2 & 4 & 0.47 & 812 & 852 & 814 & 848 \\
\hline $\mathrm{Ti}_{50} \mathrm{Ni}_{22} \mathrm{Cu}_{25} \mathrm{Sn}_{3}$ * & - & 20 & 0 & 4 & 0.53 & 697 & 758 & 697 & 754 \\
\hline $\mathrm{Ti}_{50} \mathrm{Ni}_{20} \mathrm{Cu}_{25} \mathrm{Sn}_{5}$ * & - & 20 & 6 & 4 & 0.52 & 702 & 767 & 696 & 763 \\
\hline $\mathrm{Ti}_{50} \mathrm{Ni}_{20} \mathrm{Cu}_{20} \mathrm{Sn}_{10}$ * & - & 20 & 4 & 3 & 0.39 & 731 & 774 & 727 & 771 \\
\hline $\mathrm{Ti}_{50} \mathrm{Ni}_{22} \mathrm{Cu}_{22} \mathrm{~V}_{6} *$ & - & 19 & - & 3 & 0.41 & - & 733 & - & 730 \\
\hline $\mathrm{Zr}_{65} \mathrm{Al}_{7.5} \mathrm{Ni}_{10} \mathrm{Cu}_{12.5} \mathrm{Y}_{5} * *$ & - & 19 & - & 1 & 0.15 & - & 665 & - & 664 \\
\hline $\mathrm{Si}_{45} \mathrm{Al}_{20} \mathrm{Fe}_{10} \mathrm{Ge}_{10} \mathrm{Ni}_{5} \mathrm{Cr}_{5} \mathrm{Zr}_{5}$ *** & 27 & 22 & - & 2 & 0.27 & - & 752 & & 750 \\
\hline $\mathrm{Al}_{85} \mathrm{Ni}_{5} \mathrm{Co}_{2} \mathrm{Y}_{6} \mathrm{Pd}_{2}^{* * * *}$ & 28 & 19 & - & 0 & 0.00 & - & 523 & - & 523 \\
\hline $\mathrm{Cu}_{60} \mathrm{Zr}_{30} \mathrm{~V}_{10} * * * * *$ & - & 18 & - & 12 & 1.52 & - & 790 & - & 778 \\
\hline $\mathrm{Zr}_{50} \mathrm{Cu}_{50}^{* * * * *}$ & 29 & 17 & - & 54 & 8 & 675 & 742 & - & 688 \\
\hline
\end{tabular}

* unpublished yet results; ${ }^{* *}$ amorphous+crystalline $\mathrm{Zr}$; ${ }^{* * *}$ amorphous+nanoscale $\mathrm{Ge} ;{ }^{* * * *}$ amorphous+nanoscale $\mathrm{Al} ;{ }^{* * * * *}$ initially amorphous but oxidized and partly crystallized forming micron scale $\mathrm{Cu}$ crystals. 


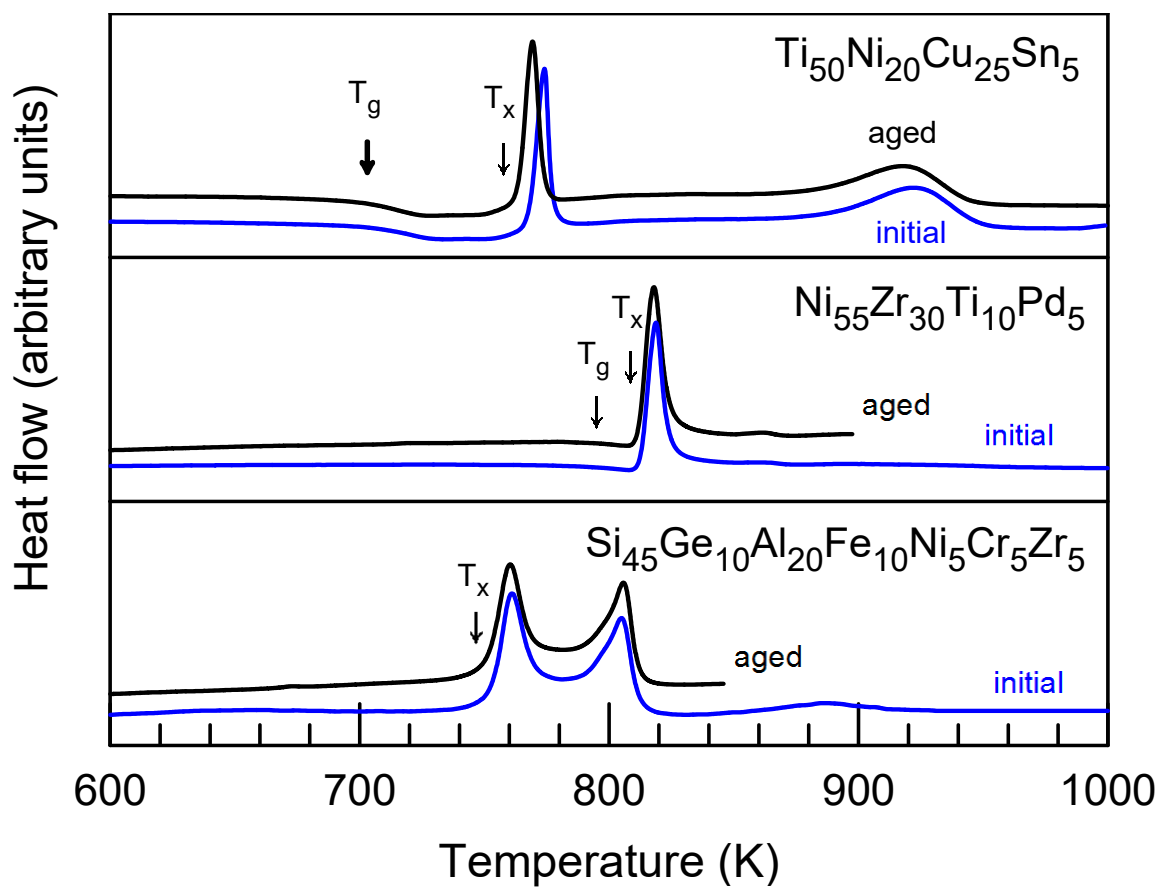

(a)

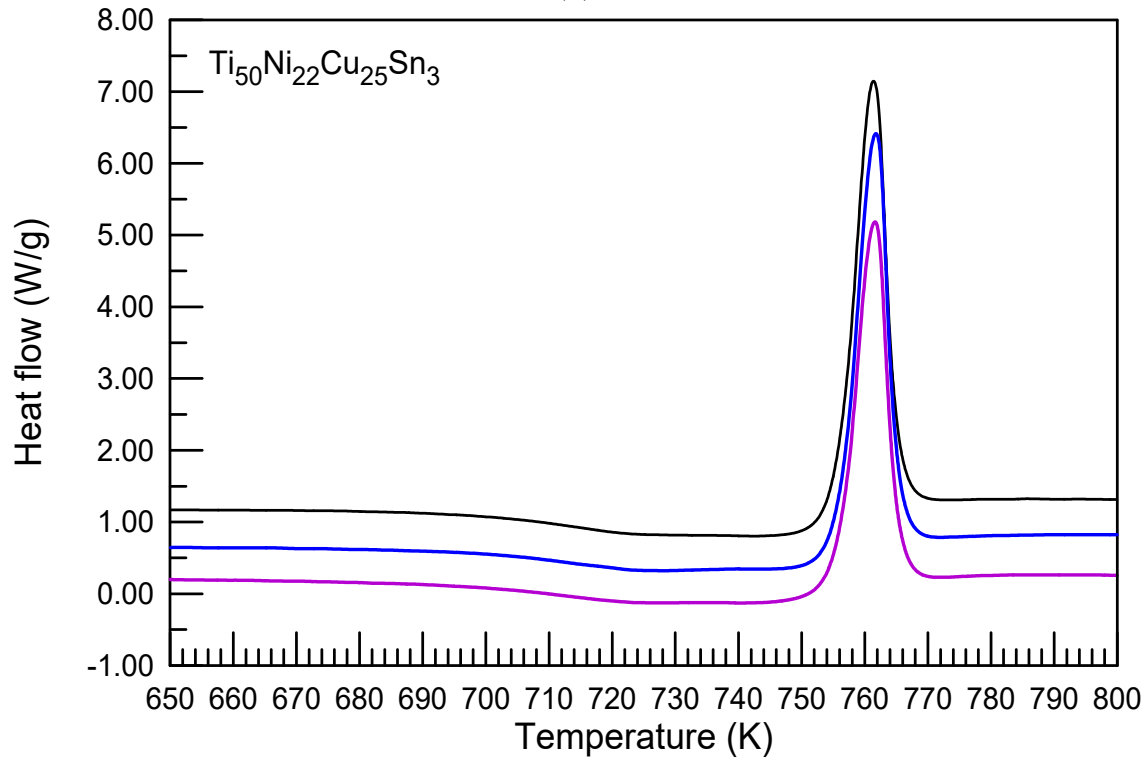

(b)

Figure 1. (a) DSC traces of some glasses and a partly crystalline material as indicated in the initial (as-cast) and naturally aged state. (b) A series of independent measurements for the $\mathrm{Ti}_{50} \mathrm{Ni}_{22} \mathrm{Cu}_{25} \mathrm{Sn}_{3}$ alloy after the aging at room temperature for 20 years as indicated in Table 1. 

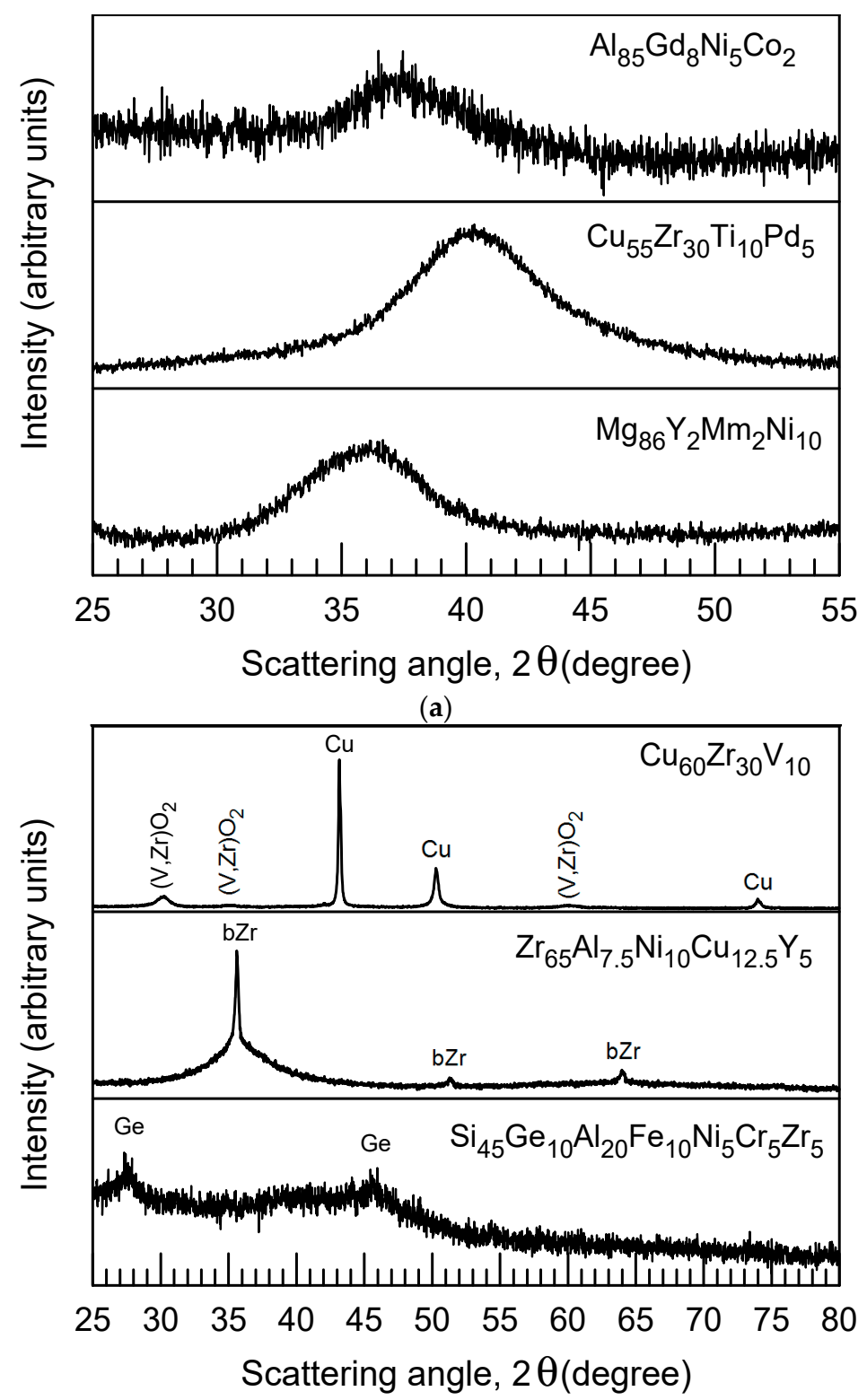

(b)

Figure 2. XRD patterns of the glassy (a) and partly crystalline alloys (b) after room-temperature aging as indicated in Table 1. bZr denotes beta Zr solid solution.

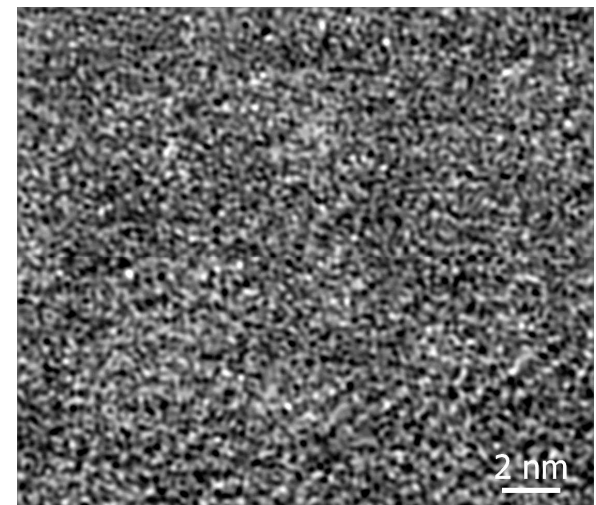

(a)

Figure 3. Cont. 


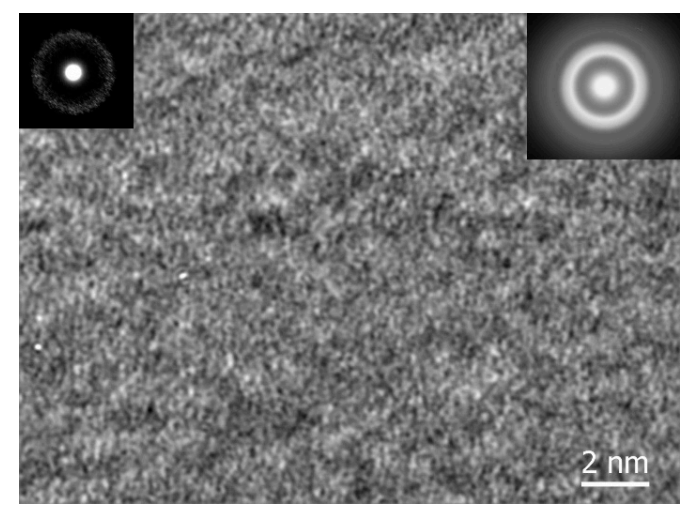

(b)

Figure 3. HRTEM images of (a) the $\mathrm{Al}_{85} \mathrm{Gd}_{8} \mathrm{Ni}_{5} \mathrm{Co}_{2}$ glassy alloy and (b) of the glassy area in the $\mathrm{Zr}_{65} \mathrm{Al}_{7.5} \mathrm{Ni}_{10} \mathrm{Cu}_{12.5} \mathrm{Y}_{5}$ alloy naturally aged for 17 years. The inserts in (a) are typical nanobeam diffraction (NBD) and selected area electron (SAED) patterns (left and right side, respectively).

$\mathrm{Cu}$-based alloys are not oxidized if they contain at least Ti. It is connected with good protective properties of the surface films containing both $\mathrm{Ti}$ and $\mathrm{Zr}$ oxides [31,32]. However, the binary $\mathrm{Zr}_{50} \mathrm{Cu}_{50}$ (Figure 4) and ternary $\mathrm{Cu}_{60} \mathrm{Zr}_{30} \mathrm{~V}_{10}$ (Figure $2 \mathrm{~b}$ ) alloys are severely oxidized. The $\mathrm{Cu}_{60} \mathrm{Zr}_{30} \mathrm{~V}_{10}$ ribbon samples are deeply oxidized forming a nanocrystalline tetragonal $(\mathrm{Z}, \mathrm{V}) \mathrm{O}_{2}$ oxide and demonstrate brown color on both sides. The surface layer consisting of $\mathrm{Cu}$ and the oxide is so deep that no signal from the amorphous phase was detected. The initial exothermic reaction likely related to the growth of pre-existing $\mathrm{Cu}$ crystals started at $438 \mathrm{~K}$ instead of $790 \mathrm{~K}$ shown in Table 1 for the as-cast alloy. The second peak related to crystallization of the glassy matrix below the oxide phase started at $778 \mathrm{~K}$, which is $12 \mathrm{~K}$ lower than that for the initial as-prepared sample.

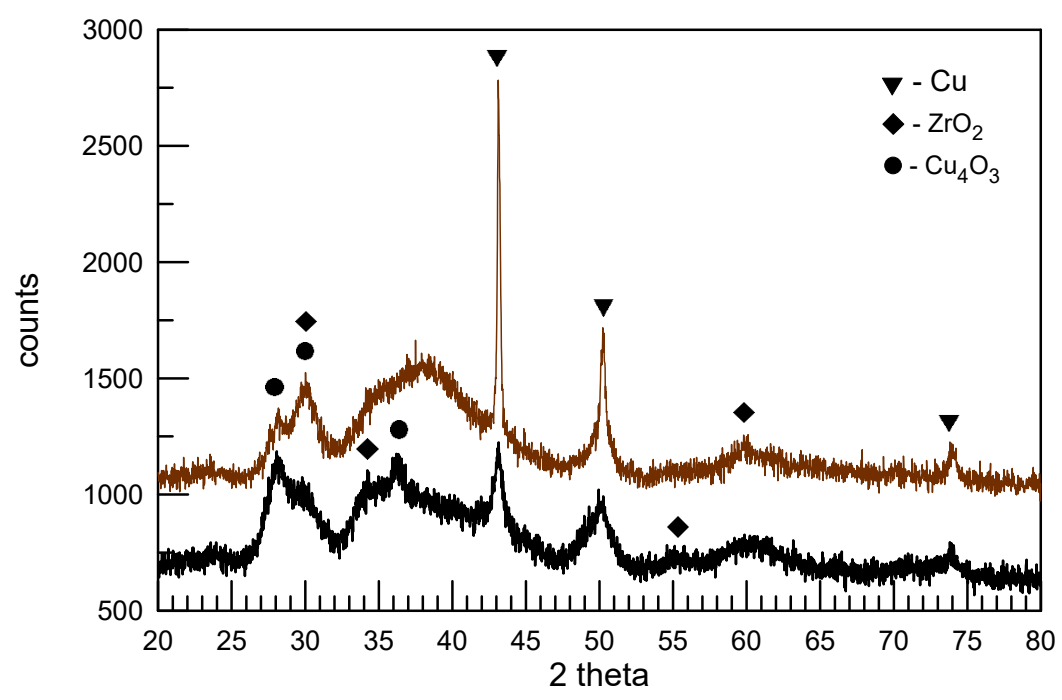

Figure 4. $\mathrm{XRD}$ patterns of the $\mathrm{Zr}_{50} \mathrm{Cu}_{50}$ sample naturally aged for 17 years. Brown (upper one)—from brown side, black (lower one )-from silver side of the ribbon.

The $\mathrm{Zr}_{50} \mathrm{Cu}_{50}$ sample was prepared and initially studied in 2002 while the results were published in 2007 together with these for the $\mathrm{Zr}-\mathrm{Cu}$-Al alloys [29]. The $\mathrm{Zr}_{50} \mathrm{Cu}_{50}$ metallic glassy ribbon samples have two sides of different color. Free side which was in contact with air on rapid solidification is dark silver metallic while the side which was in contact with a copper wheel and has a rougher surface is brown. However, in this alloy the oxide layer is thinner than in the $\mathrm{Cu}_{60} \mathrm{Zr}_{30} \mathrm{~V}_{10}$ sample and a strong enough broad peak from the amorphous phase is obtained between 32 and 45 degrees of 2 theta (Figure 4). 
Here, as well as in the case of the $\mathrm{Cu}_{60} \mathrm{Zr}_{30} \mathrm{~V}_{10}$ alloy, nanocrystalline oxides (orthorhombic $\mathrm{ZrO}_{2}$ and tetragonal $\mathrm{Cu}_{4} \mathrm{O}_{3}$ one) are formed while $\mathrm{Cu}$ crystallized on the surface (see Figure 4). Larger, micrometer-scale particles are formed on the rough ribbon surface, which was in contact with $\mathrm{Cu}$ wheel though $\mathrm{Cu}$ oxide, is also formed. The $\mathrm{Zr}_{50} \mathrm{Cu}_{50}$ sample was studied by SEM on both sides (Figure 5). Rough micron-scale crystals are seen on the brown surface while the dark silver metallic surface was smooth. EDX spectral analysis showed that the micron-scale particles are Cu crystals (Table 2).

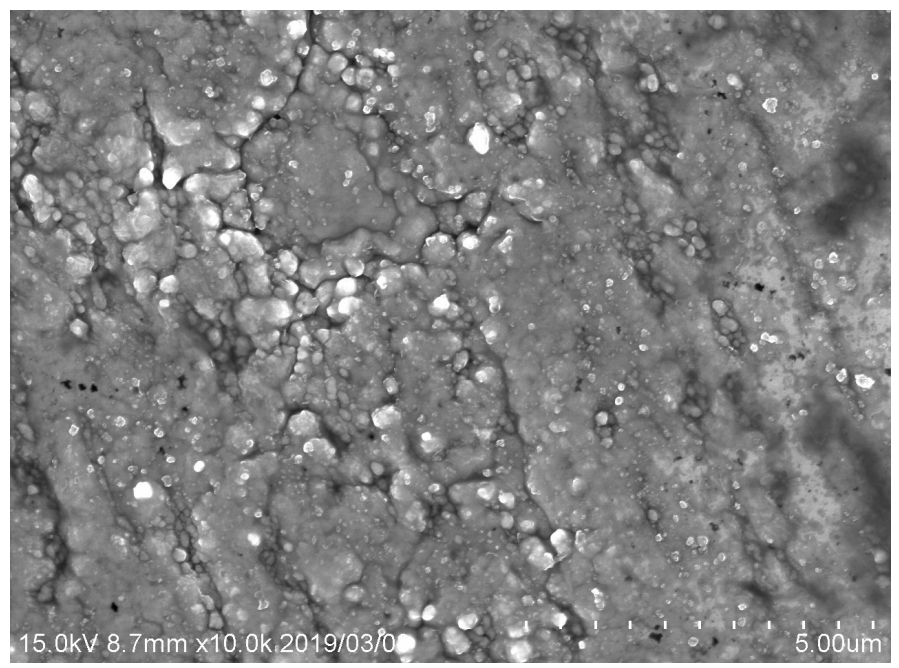

(a)

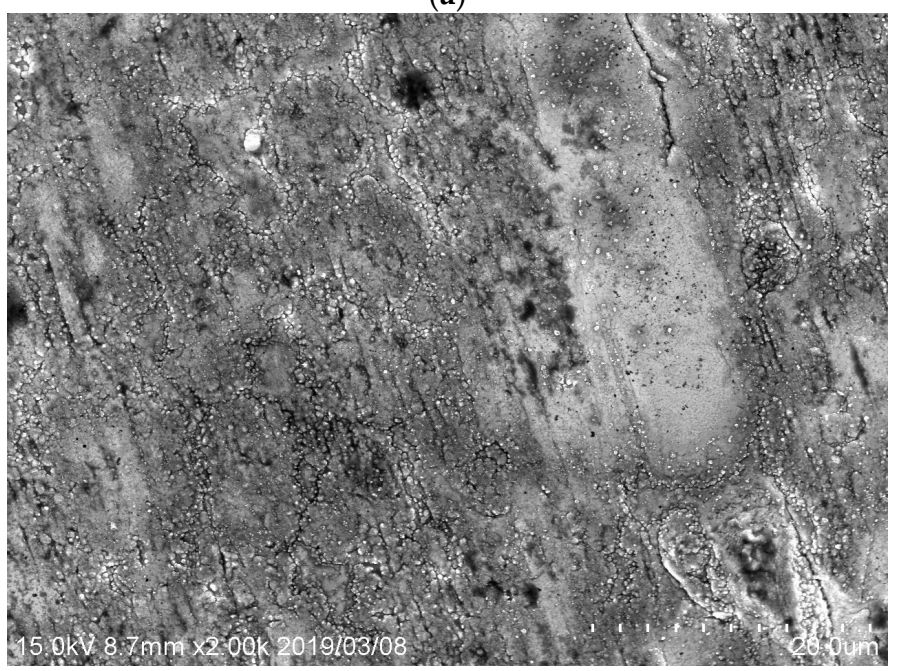

(b)

Figure 5. SEM images of the $\mathrm{Zr}_{50} \mathrm{Cu}_{50}$ sample naturally aged for 17 years. (a) Brown side and (b) silver side.

\section{Discussion}

Most of the metallic glasses stored at ambient conditions for more than 15 years studied in the present work retained the original silver metallic color and their initial either glassy or partly crystalline structure. The X-ray diffraction and transmission electron microscopy observations confirmed preservation of the glassy structure. Although the crystallization temperature is slightly reduced after natural aging the reduction is only a few Kelvin (from 1 to $4 \mathrm{~K}$ depending on composition (Table 1)) which is negligibly small from the viewpoint of industrial application. It confirms high room-temperature stability of metallic glasses suggested in the earlier works [17,19]. The reduction of the crystallization temperature is likely connected with natural structural relaxation of the glassy 
phase, a minor surface oxidation and contamination with the organic substances, which can enhance surface induced crystallization by activating heterogeneous nucleation [33].

Table 2. Chemical composition in at $\%$ of both sizes of the $\mathrm{Zr}_{50} \mathrm{Cu}_{50}$ glassy ribbon naturally aged for 17 years, SEM, EDX.

\begin{tabular}{cccc}
\hline Area & Side & $\mathbf{C u}$ & $\mathbf{Z r}$ \\
\hline Smooth area & silver & 52.6 & 47.4 \\
Smooth area & silver & 52.6 & 47.4 \\
Smooth area & silver & 51.1 & 48.9 \\
Average & - & 52.1 & 47.9 \\
C.I. * & - & \pm 1.2 & \pm 1.2 \\
Smooth area & brown & 57.1 & 42.9 \\
Smooth area & brown & 58.4 & 41.6 \\
Average & - & 57.75 & 42.25 \\
Particle area & brown & 67.4 & 32.6 \\
\hline \multicolumn{4}{c}{${ }^{*}$ confidence interval. }
\end{tabular}

Precipitation of micron-scale $\mathrm{Cu}$ crystals at room temperature found in some $\mathrm{Cu}$-rich glasses requires long-range diffusion. It was reported [34] that although oxidation of the $\mathrm{Zr}_{50} \mathrm{Cu}_{50}$ alloy on heating at $500-700{ }^{\circ} \mathrm{C}$ starts from preferential oxidation of zirconium copper forms $\mathrm{Cu}_{51} \mathrm{Zr}_{14}$ phase at the metal/oxide interface. Cu-enriched layer was also found to form at the metal/oxide interface in subsequent research works $[35,36]$. Moreover, the alloy did not oxidize noticeably below $400{ }^{\circ} \mathrm{C}$. Nevertheless, oxidation on heating takes place in rather dry environment while air humidity alters the oxidation mechanism at room temperature leading to electrochemical corrosion, and thus, enhanced surface diffusivity of $\mathrm{Cu}$.

Crystallization $[37,38]$ and electrochemical corrosion $[39,40]$ of the $\mathrm{Zr}_{50} \mathrm{Cu}_{50}$ glassy alloy were studied extensively. A recent work particularly reflected its complicated crystallization behavior [41]. Higher $\mathrm{Cu}$ content causes an increase in the passivation current of $\mathrm{Cu}-\mathrm{Zr}$ glassy alloys [42]. The competition between oxidation of $\mathrm{Zr}$ atoms forming $\mathrm{ZrO}_{2}$ film owing to its high formation enthalpy with oxygen and the oxidation-induced segregation of $\mathrm{Cu}$ atoms plays an important role in the electrochemical behavior of the $\mathrm{Zr}-\mathrm{Cu}$ glassy coatings [43].

According to the Ellingham diagrams [44] there is a large difference in the Gibbs Free Energy change on the formation of zirconium and copper oxides. Even at very low concentrations of zirconium in a copper melt containing oxygen, copper oxide formation is thermodynamically unlikely [45] because $\mathrm{Zr}$ acts as a flux. Thus, $\mathrm{Cu}$ is repulsed from $\mathrm{ZrO}_{2}$ matrix and clustered as pure $\mathrm{Cu}$. Although nanocrystalline $\mathrm{Cu}$ was formed on the surface of $\mathrm{Zr}_{70} \mathrm{Cu}_{30}$ metallic glass stored for eight years [33] here we show the formation of microcrystalline $\mathrm{Cu}$ at room temperature at ambient conditions.

An open question is why no intermediate $\mathrm{Cu}-\mathrm{Zr}$ intermetallic compounds are formed on the surface of $\mathrm{Zr}_{50} \mathrm{Cu}_{50}$ and $\mathrm{Cu}_{60} \mathrm{Zr}_{30} \mathrm{~V}_{10}$ alloys in accordance with the $\mathrm{Cu}-\mathrm{Zr}$ phase diagram but pure $\mathrm{Cu}$ ? Although the glassy phase rather easily forms in the alloys containing as much as $70 \mathrm{at} \% \mathrm{Cu}$ and more [46] formation of $\mathrm{Cu}_{51} \mathrm{Zr}_{14}$ (hP65) phase with high thermal stability as well as $\mathrm{Cu}_{9} \mathrm{Zr}_{2}$ (tP24) or $\mathrm{Cu}_{8} \mathrm{Zr}_{3}$ (oP44) should be possible [47] at an intermediate state when the glassy phase becomes gradually diluted in $\mathrm{Zr}$. A reasonable explanation is connected with difficulties in bypassing the energy barrier for nucleation of these phases at room temperature.

It is also known that $\mathrm{Zr}-\mathrm{Cu}$-based glassy alloys are, in general, predisposed to show clustering of $\mathrm{Cu}$ near the surface. For example, a homogeneous $\mathrm{Zr}-\mathrm{Al}$ amorphous oxide film was formed in several munities on the surface of the $\mathrm{Cu}_{47} \mathrm{Zr}_{45} \mathrm{Al}_{8}$ metallic glassy alloy while $\mathrm{Cu}$ segregated at the metal/oxide interface [48]. The $\mathrm{Cu}_{2} \mathrm{O}$ nanoparticles were also formed within the $\mathrm{Zr}-\mathrm{Al}$ amorphous oxide film. Moreover, pure $\mathrm{Cu}$ precipitated within the $\mathrm{Zr}-\mathrm{Cu}$ glassy layers on annealing [49]. Cu-rich layer was also formed on the surface of $\mathrm{Zr}-\mathrm{Cu}-\mathrm{Fe}-\mathrm{Al}$ and $\mathrm{Zr}-\mathrm{Cu}-\mathrm{Ni}-\mathrm{Al}$ metallic glasses subjected to cryogenic cycling treatment [50]. 


\section{Conclusions}

Most of the studied metallic glasses stored at ambient conditions for more than 15 years retained the original silver metallic color and initial either glassy or partly crystalline structure. No visible changes in the X-ray diffraction patterns are found. Transmission electron microscopy observation also confirmed preservation of the glassy structure in two alloys. Although the crystallization temperature is slightly reduced after more than 15 years of natural aging the reduction is only a few Kelvin. The results directly confirm high room-temperature stability of metallic glasses.

The aged Cu-based alloys are not oxidized (only a native thin film is observed) if they contain at least Ti. However, the binary $\mathrm{Zr}_{50} \mathrm{Cu}_{50}$ and ternary $\mathrm{Cu}_{60} \mathrm{Zr}_{30} \mathrm{~V}_{10}$ alloys are severely oxidized. Moreover, precipitation of micron-scale $\mathrm{Cu}$ crystals was found in both alloys at room temperature as a result of surface oxidation at natural humidity indicating fast surface diffusion.

Author Contributions: Conceptualization, D.V.L.-L. and J.J.; formal analysis, D.V.L.-L.; investigation, D.V.L.-L.; data curation, D.V.L.-L. and J.J.; writing—review and editing, D.V.L.-L. and J.J.

Funding: This research was funded by the World Premier International Research Center Initiative (WPI), MEXT, Japan.

Conflicts of Interest: The authors declare no conflict of interest.

\section{References}

1. Greer, A.L. New horizons for glass formation and stability. Nat. Mater. 2015, 14, 542-546. [CrossRef] [PubMed]

2. Suryanarayana, C.; Inoue, A. Bulk Metallic Glasses; CRC Press: Boca Raton, FL, USA, 2011; p. 543.

3. Louzguine-Luzgin, D.V. Metallic Glasses and Those Composites; Materials Research Forum LLC: Millersville, PA, USA, 2018; p. 336.

4. Kaloshkin, S.D.; Tomilin, I.A. The crystallization kinetics of amorphous alloys. Thermochim. Acta 1996, 280-281, 303-317. [CrossRef]

5. Liu, F.; Sommer, F.; Bos, C.; Mittemeijer, E.J. Analysis of solid state phase transformation kinetics: Models and recipes. Int. Mater. Rev. 2007, 52, 193-212. [CrossRef]

6. Perepezko, J.H. Nucleation-controlled reactions and metastable structures. Prog. Mater Sci. 2004, 49, $263-284$. [CrossRef]

7. Louzguine, D.V.; Inoue, A. Strong influence of supercooled liquid on crystallization of the $\mathrm{Al}_{85} \mathrm{Ni}_{5} \mathrm{Y}_{4} \mathrm{Nd}_{4} \mathrm{Co}_{2}$ metallic glass. Appl. Phys. Lett. 2001, 78, 3061-3063. [CrossRef]

8. Zhang, B.; Zhao, D.Q.; Pan, M.X.; Wang, W.H.; Greer, A.L. Amorphous metallic plastic. Phys. Rev. Lett. 2005, 94, 205502. [CrossRef] [PubMed]

9. Zhao, K.; Li, J.F.; Zhao, D.Q.; Pan, M.X.; Wang, W.H. Degradable Sr-based bulk metallic glasses. Scr. Mater. 2009, 61, 1091-1094. [CrossRef]

10. Louzguine-Luzgin, D.V.; Polkin, V.I. Properties of bulk metallic glasses. Russ. J. Non-Ferrous Met. 2017, 58, 80-92. [CrossRef]

11. Madge, S.V. Toughness of bulk metallic glasses. Metals 2015, 5, 1279-1305. [CrossRef]

12. Peker, A.; Johnson, W.L. Time-temperature-transformation diagram of a highly processable metallic glass. Mater. Sci. Eng. A 1994, 179-180, 173-175. [CrossRef]

13. Bai, F.X.; Yao, J.H.; Wang, Y.X.; Pan, J.; Li, Y.; Bai, F.X. Crystallization kinetics of an Au-based metallic glass upon ultrafast heating and cooling. Scr. Mater. 2017, 132, 58-62. [CrossRef]

14. Nishiyama, N.; Inoue, A. Supercooling investigation and critical cooling rate for glass formation in Pd-Cu-Ni-P alloy. Acta Mater. 1999, 47, 1487-1495. [CrossRef]

15. Loeffler, J.; Schroers, J.; Johnson, W.L. Time-temperature-transformation diagram and microstructures of bulk glass forming $\mathrm{Pd}_{40} \mathrm{Cu}_{30} \mathrm{Ni}_{10} \mathrm{P}_{20}$. Appl. Phys. Lett. 2000, 77, 681-683. [CrossRef]

16. Louzguine, D.V.; Inoue, A. Comparison of the long-term thermal stability of various metallic glasses under continuous heating. Scr. Mater. 2002, 47, 887-891. [CrossRef]

17. Louzguine-Luzgin, D.V.; Inoue, A. Relation between time-temperature transformation and continuous heating transformation diagrams of metallic glassy alloys. Physica B 2005, 358, 174-180. [CrossRef] 
18. Grange, R.A.; Kiefer, J.M. Transformation of austenite on continuous cooling and its relation to transformation at constant temperature. Trans. ASM 1941, 29, 85-144.

19. Louzguine-Luzgin, D.V.; Inoue, A. The outline of glass transition phenomenon derived from the viewpoint of devitrification process. Phys. Chem. Glasses-Eur. J. Glass Sci. Technol., Part B 2009, 50, 27-30.

20. Louzguine, V.; Inoue, A. Electronegativity of the constituent rare-earth metals as a factor stabilizing the supercooled liquid region in Al-based metallic glasses. Appl. Phys. Lett. 2001, 79, 3410-3412. [CrossRef]

21. Louzguine, D.V.; Inoue, A. Comparative analysis of crystallization of $\mathrm{Al}_{85} \mathrm{RE}_{8} \mathrm{Ni}_{5} \mathrm{Co}_{2}$ (RE-rare earth metals), metallic glasses with and without supercooled liquid region. J. Metastable Nanocryst. Mater. 2002, 386-388, 117-122.

22. Louzguine, D.V.; Louzguina, L.V.; Inoue, A. Multistage devitrification of Mg-Ni-Mm and Mg-Ni-Y-Mm metallic glasses $(\mathrm{Mm}=$ mischmetal). Philos. Mag. A 2003, 83, 203-216. [CrossRef]

23. Louzguine, D.V.; Inoue, A. Gold as an alloying element promoting formation of a nanoicosahedral phase in a Cu-based alloy. J. Alloys Compd. 2003, 361, 153-156. [CrossRef]

24. Louzguine, D.V.; Inoue, A. Nanoparticles with icosahedral symmetry in Cu-based bulk glass former induced by Pd addition. Scr. Mater. 2003, 48, 1325-1329. [CrossRef]

25. Louzguine, D.V.; Inoue, A. Influence of Ni and Co additions on supercooled liquid region, devitrification behaviour and mechanical properties of $\mathrm{Cu}-\mathrm{Zr}$-Ti bulk metallic glass. In Proceedings of the 9th International Symposium on Metastable, Mechanically Alloyed and Nanocrystalline Materials, Seoul, Korea, 8-12 September 2002.

26. Louzguine, D.V.; Inoue, A. Devitrification of Ni-based glassy alloys containing noble metals in relation with the supercooled liquid region. J. Non-Cryst. Solids 2004, 337, 161-165. [CrossRef]

27. Louzguine, D.V.; Inoue, A. Microstructure and properties of melt-spun Si-Al-Ge-Transition Metal amorphous alloys containing nanocrystalline Ge particles. Mater. Trans., JIM 1998, 39, 245-251. [CrossRef]

28. Louzguine-Luzgin, D.V.; Inoue, A. Structure and transformation behaviour of a rapidly solidified Al-Y-Ni-Co-Pd alloy. J. Alloys Compd. 2005, 399, 78-85. [CrossRef]

29. Louzguine-Luzgin, D.V.; Xie, G.; Zhang, W.; Inoue, A. Influence of Al and Ag on the devitrification behavior of a Cu-Zr glassy alloy. Mater. Trans. 2007, 48, 2128-2132. [CrossRef]

30. Battezzati, L. Interplay of process kinetics in the undercooled melt in the proximity of the glass transition. Mater. Sci. Eng., A 2004, 375-377, 60-65. [CrossRef]

31. Debnath, M.R.; Kim, D.-H.; Fleury, E. Dependency of the corrosion properties of in-situ Ti-based BMG matrix composites with the volume fraction of crystalline phase. Intermetallics 2012, 22, 255-259. [CrossRef]

32. Lee, P.Y.; Cheng, Y.M.; Chen, J.Y.; Hu, C.J. Formation and corrosion behavior of mechanically-alloyed Cu-Zr-Ti bulk metallic glasses. Metals 2017, 7, 148. [CrossRef]

33. Koster, U. Surface crystallization of metallic glasses. Mater. Sci. Eng. 1988, 97, 233-239. [CrossRef]

34. Paljević, M.; Tudja, M. Unusual oxidation behaviour of $\mathrm{Zr}_{50} \mathrm{Cu}_{50}$ alloy at high temperatures. Corros. Sci. 2008, 50, 818-822. [CrossRef]

35. Lim, K.; Kim, W.; Lee, E.; Jee, S.; Kim, S.; Kim, D.; Eckert, J. Oxidation resistance of the supercooled liquid in $\mathrm{Zr}_{50} \mathrm{Cu}_{50}$ and $\mathrm{Cu}_{46} \mathrm{Zr}_{46} \mathrm{Al}_{8}$ metallic glasses. J. Mater. Res. 2012, 27, 1178-1186. [CrossRef]

36. Lim, K.R.; Kim, C.E.; Yun, Y.S.; Kim, W.T.; Soon, A.; Kim, D.H. Remarkably stable amorphous metal oxide grown on $\mathrm{Zr}-\mathrm{Cu}$-Be metallic glass. Sci. Rep. 2015, 5, 18196. [CrossRef]

37. Altounian, Z.; Guo-hua, T.; Strom-Olsen, J.O. Crystallization characteristics of Cu-Zr metallic glasses from $\mathrm{Cu}_{70} \mathrm{Zr}_{30}$ to $\mathrm{Cu}_{25} \mathrm{Zr}_{75}$. J. Appl. Phys. 1982, 53, 4755. [CrossRef]

38. Freed, R.L.; Vander Sande, J.B. A study of the crystallization of two non-crystalline Cu-Zr alloys. J. Non-Cryst. Solids 1978, 27, 9-28. [CrossRef]

39. Naka, M.; Hashimoto, K.; Masumoto, T. Corrosion behavior of amorphous and crystalline $\mathrm{Cu}_{50} \mathrm{Ti}_{50}$ and $\mathrm{Cu}_{50} \mathrm{Zr}_{50}$ alloys. J. Non-Cryst. Solids 1978, 30, 29-36. [CrossRef]

40. Turn, J.C.; Latanision, R.M. The influence of structure on the corrosion of glassy copper-zirconium alloys. Natl. Assoc. Corros. Eng. 1983, 39, 271-279. [CrossRef]

41. Cullinan, T.; Kalay, I.; Kalay, Y.E.; Kramer, M.; Napolitano, R. Kinetics and mechanisms of isothermal devitrification in amorphous $\mathrm{Cu}_{50} \mathrm{Zr}_{50}$. Metall. Mater. Trans. A 2015, 46A, 600. [CrossRef]

42. Bala, H.; Szymura, S. Acid corrosion of amorphous and crystalline Cu-Zr alloys. Appl. Surf. Sci. 1988, 35, 41-51. [CrossRef] 
43. Tang, J.; Zhu, Q.H.; Wang, Y.Y.; Apreutesei, M.; Wang, H.; Steyer, P.; Chamas, M.; Billard, A. Insights on the role of copper addition in the corrosion and mechanical properties of binary $\mathrm{Zr}-\mathrm{Cu}$ metallic glass coatings. Coatings 2017, 7, 223. [CrossRef]

44. Ellingham, H.J.T. Reducibilty of oxides and sulphides in metallurgical processes. J. Soc. Chem. Ind. Lond. 1944, 63, 125.

45. Samoylova, O.V.; Mikhailov, G.G.; Makrovets, L.A.; Trofimov, E.A. Thermodynamic analysis of interaction processes in the Cu-Zr-O system realized in liquid copper melt. Bull. South Ural State Univ. Ser. Metall. 2014, $14,17-22$.

46. Li, Y.; Guo, Q.; Kalb, J.A.; Thompson, C.V. Matching glass-forming ability with the density of the amorphous phase. Science 2008, 322, 1816-1819. [CrossRef] [PubMed]

47. Han, X.L.; Qin, Y.S.; Qin, K.; Li, X.L.; Wang, S.H.; Mi, J.; Song, K.K.; Wang, L. Glass-forming ability and early crystallization kinetics of novel Cu-Zr-Al-Co bulk metallic glasses. Metals 2016, 6, 225. [CrossRef]

48. Louzguine-Luzgin, D.V.; Chen, C.L.; Lin, L.Y.; Wang, Z.C.; Ketov, S.V.; Miyama, M.J.; Trifonov, A.S.; Lubenchenko, A.V.; Ikuhara, Y. Bulk metallic glassy surface native oxide: Its atomic structure, growth rate and electrical properties. Acta Mater. 2015, 97, 282-290. [CrossRef]

49. Ketov, S.V.; Ivanov, Y.P.; Şopu, D.; Louzguine-Luzgin, D.V.; Suryanarayana, C.; Rodin, A.O.; Schöber, T.; Greer, A.L.; Eckert, J. High-resolution transmission electron microscopy investigation of diffusion in metallic glass multilayer films. Mater. Today Adv. 2019, 1, 100004. [CrossRef]

50. Ketov, S.V.; Trifonov, A.S.; Ivanov, Y.P.; Churyumov, A.Y.; Lubenchenko, A.V.; Batrakov, A.A.; Jiang, J.; Louzguine-Luzgin, D.V.; Eckert, J.; Orava, J.; et al. On cryothermal cycling as a method for inducing structural changes in metallic glasses. NPG Asia Mater. 2018, 10, 137-145. [CrossRef]

(C) 2019 by the authors. Licensee MDPI, Basel, Switzerland. This article is an open access article distributed under the terms and conditions of the Creative Commons Attribution (CC BY) license (http://creativecommons.org/licenses/by/4.0/). 